\title{
The Impact of Technology and Globalization on Employment and Equity: An Organizing Framework for Action
}

\author{
Bernard Arogyaswamy (Corresponding Author) \\ Madden School of Business, LeMoyne College, Syracuse, New York \\ E-mail: arogyas@lemoyne.edu \\ John Hunter \\ Madden School of Business, LeMoyne College, Syracuse, New York \\ E-mail: hunterjg@lemoyne.edu
}

Received: December 29, 2018 Accepted: August 10, 2019 Published: August 12, 2019

doi:10.5296/ijgs.v3i1.14127 URL: https://doi.org/10.5296/ijgs.v3i1.14127

\begin{abstract}
The United States has experienced a decline in the number of well-paid manufacturing jobs requiring no more than a high school diploma, as well as of middle-income knowledge economy jobs. Globalization is, indeed, as many suggest, partly responsible for this problem. Other factors have, however, played an equally, if not more, significant role. Technological advancements, the decline of labor's bargaining power, and the sharply increased financialization of the economy are among the factors which have contributed to the loss of manufacturing and service sector jobs, the creation of new types of tasks for which there are not enough qualified applicants, and a widening of income inequality. With the help of the Pressure-State-Response (PSR) system, we discuss each of these four factors taken individually and collectively (i.e. the Pressure), which result in the outcomes or States. The Responses discuss actions taken to address the negative effects of the P-S. We also propose responses which might be considered, and contend that training/retraining programs need to be redesigned, corporations need to play a more active role in dealing with societal disruptions, and that governments have a crucial role to play in ensuring economic and social stability. It needs to be emphasized that, particularly in regard to technology and the mutually reinforcing relationship between technology and globalization, which has transformed the
\end{abstract}


nature of work, future impacts on employment and inequality) may well be even more powerful than in in the past.

Keywords: Technology, Globalization, Labor power, Jobs-skills gaps, CSR, Inequality, Social mobility

\section{Introduction- A Framework for Analysis}

Over the past three decades the process of "globalization", broadly defined as the rising interconnections among, and integration of, nations through trade, travel, telecommunications, and other means (Stiglitz, 2007; Bhagwati, 2007; Steger, 2017), has evolved, and expanded to include numerous countries, products/services, and activities. Corporations have adopted strategies to take advantage of lowered tariffs, subsidies and incentives offered by host governments, and an institutional regimen which has evolved to support and facilitate the free flow of goods and services across borders. As firms moved functions and processes offshore to reap location advantages, work was generally assigned to countries or regions marked by low costs, where the governments provided better facilities, and labor with superior skill levels was at hand (Sahoo, Dash, \& Nataraj, 2010; Guthrie, 2012). This shifting of the locus of task performance and investment with a view to increasing profits generated by transnational corporations (TNCs) has often resulted in declining employment in developed nations across a variety of industries, starting with low value-added manufacturing, but gradually expanding to include higher skill-level jobs both in manufacturing and in services. The increasing disquiet over, indeed, hostility towards, the offshoring of jobs has, therefore, some basis in reality. It does not, however, tell the entire story of ongoing job displacements and lack of skilled applicants for the jobs being created.

In this paper, we argue that the decline in the number of middle-income, knowledge economy jobs in the United States and other developed nations is, indeed, partly an outcome of globalization, but other factors have played an equally, if not more, significant role. Technological advancements, the decline of labor's bargaining power, and the sharply increased financialization of the economy (Lin \& Tomaskovic-Devey, 2013; Harris, 2015; Vachon, Wallace, \& Hyde, 2016) are among the factors which have contributed to the loss of manufacturing and service sector jobs, the creation of new types of tasks for which there not enough qualified applicants, and a widening of the income gap. While considerable work has been done in delineating the social, political, and economic challenges facing developed nations, the solutions proposed typically revolve around public policy and governmental actions. We argue that corporations, being the prime initiators of the four forces, must be integral if not central to addressing the threats posed by technology, globalization, financialization, and marginalization of labor. With the help of the Pressure-State-Impact-Response (PSIR) system (OECD, 1998; Pissourios, 2013), we discuss each of these factors or Pressures individually and collectively. The resultant States (or outcomes), and Impacts,are analyzed next, particularly in regard to employment and equity, drawing on the considerable extant literature. In developing the Responses (R1) adopted, we discuss ways in which the negative effects of the PS combination (problems relating to employment, rising inequalities, attitudes to immigration, intellectual property protections, and so on), have been addressed, albeit not always successfully. Finally, we propose responses (R2) which are worthy of serious consideration, particularly since the states/future 


\section{Macrothink}

impacts could well be even more deleterious than those already experienced.

The figure below encapsulates the conceptual model developed in the paper. Figure 1 serves as a framework both to understanding the factors and processes involved, and the remedial and/or preemptive actions required to deal with present and future challenges.

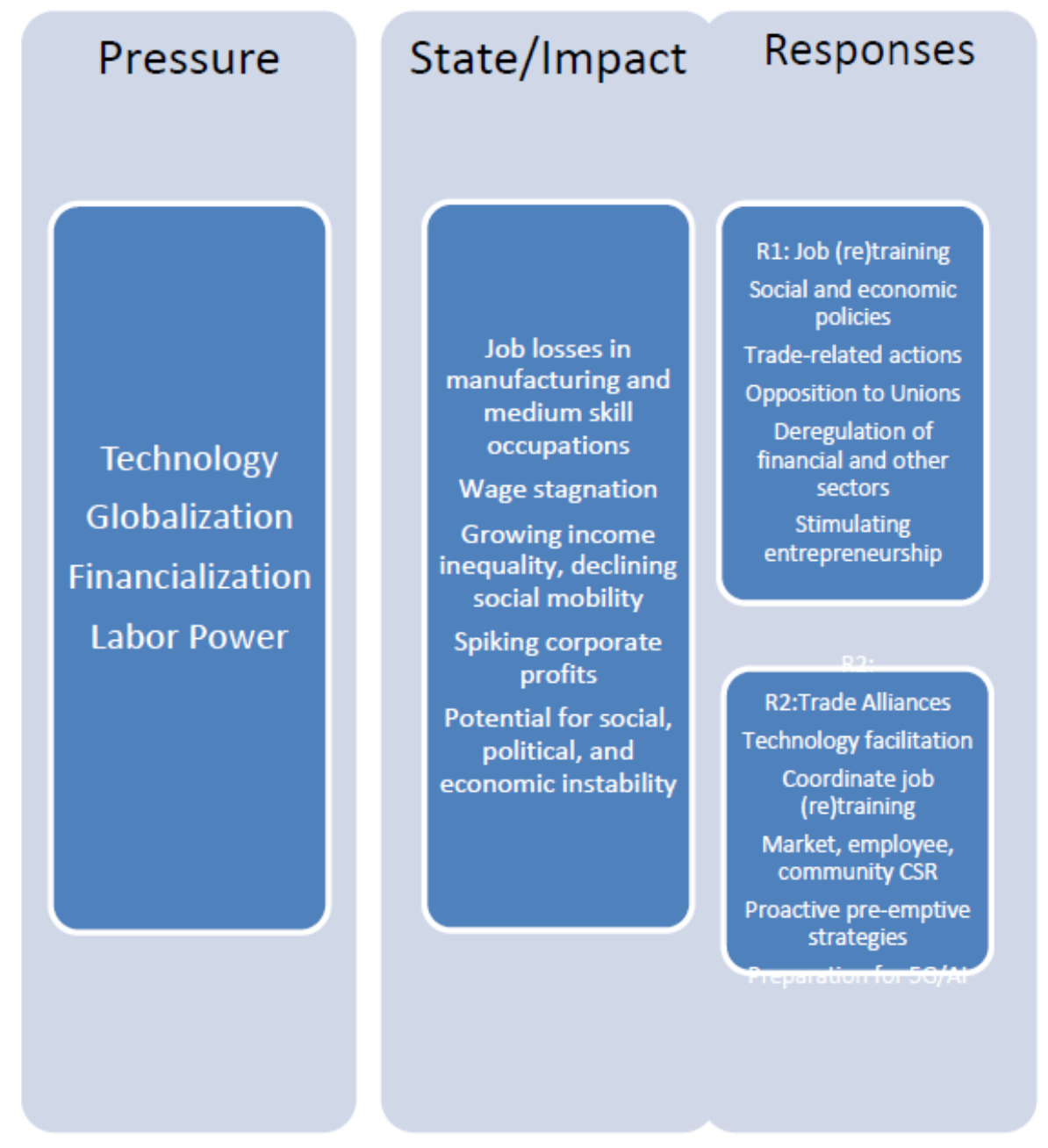

Figure 1. Addressing the challenges posed by technology, globalization, financialization, and marginalization of labor

\section{Globalization}

The ongoing process of global interconnection, has proceeded through several stages. Initially, firms contracted out production to low wage countries, shifting their locations as incomes rose, and economic growth picked up in their erstwhile manufacturing centers, at which point companies focused on marketing their products to the newly-prosperous nations (Stiglitz, 2006; Steyngart, 2008; Ghemawat, 2007). The dispersion of supply chains to gain location efficiencies also enabled multinationals to minimize costs of production, while targeting emerging nations' markets (Elms \& Low, 2013).

As more jobs, particularly at the middle-income level are outsourced, discontentment, 
bordering on hostility, with globalization and its perceived associated effects (immigration, higher disparities, technology spillovers), has risen sharply in many Western nations. The reaction has been powerful enough to cast some doubt not only on the prospects for free trade but for the stability of free market capitalism, and democracy itself (Applebaum, 2018; Levitsky \& Ziblatt, 2018; The Economist, 2018a). The issue is a highly contentious one, as Izaak (2008) observes, pitting the interests of consumers and shareholders against those of employees, of Transnational Corporations versus those of nations, poor against rich, domestic as opposed to foreign innovation, and so on. Finding solutions to the challenge posed by rising inequality, the narrowing of the technological gap between the U.S. and other countries, and the widening jobs-skills gap calls for dealing with these contradictions and addressing the needs of diverse stakeholders. However, globalization is not the only factor (or Pressure) underlying the malaise afflicting many of the world's major economies. Technology and innovation have been the most powerful forces, directly and indirectly, in their impact on societies, and the relations within and among them. (Galbraith, 2012; Financial Times, 2016)

\section{Technology and Innovation}

In addition to facilitating globalization, technological change has, by its very nature, had a significant impact on economic transactions, organizational performance, and the very nature of work itself. The development of ATMs, mobile devices, internet platforms, e-readers, lean manufacturing, techniques such as six sigma, and other such products, processes, management systems, and business models have demonstrated the multifaceted nature of technology (Arthur, 2009; Zhouying, 2004).

\subsection{Product Innovation}

In the case of radical product/service innovation, materials, suppliers, operating processes, and employee skills needed may be markedly different from those in the prevailing paradigm e.g. horse-drawn carriages being replaced by automobiles, cell phones substituting for digital cameras, e-readers in lieu of printed books, live streaming instead of cable TV and DVDs (Gordon, 2016). Employment could decline in each of the affected industries unless people employed by the industries being disrupted quickly acquire the skills necessary to succeed in the emerging businesses (Mokyr, Vickers, \& Ziebarth, 2015). Such labor mobility is rarely seen in practice since reskilling requires investment and time, perhaps moving to a new location, entering the job market at a lower position, and so on. In the case of major new technologies such as electricity, the railroads, or the automobile the number and type of new occupations and jobs created could see explosive growth (Hughes, 1983; White, 2011). Even when online retailing gains at the expense of retail stores, new employment in computer programming, customer service, shipping and packaging, etc., may be created. However the new types of jobs being created may attract an entirely new cadre of employees with new and rare skill sets, create large numbers of low paid jobs, label workers as contractors ineligible for benefits, and so on (Djankow \& Saliola, 2017).

\subsection{Process Innovation}

When new, more efficient processes for manufacturing products or creating services are developed, employment in operations could decline. Self check-ins at airports, monthly statements generated by banks, the use of automation and robotics in production, remote 
diagnostic systems, and voice-activated information desks are among the many process innovations which have eliminated the need for a variety of jobs. Admittedly, new types of work are often created (e.g the creation of the position of "relationship manager" and opening more branches to complement increased automation in banks), and entire industries may experience spurts in demand, as Heater (2017) notes, due to decreased variable costs (and hence lower prices). However, new tasks may need to be performed for which only a portion of the existing work force will have the necessary "technology-biased" skills (Siegel, 1999). This "jobs-skills gap" is a chasm that many workers who have been rendered redundant have been increasingly unable to cross (Global Markets Institute, 2016). Clearly, routine and structured tasks are more easily automated, while those requiring interaction, adaptation, and customization need more human inputs. Managerial process innovation such as Total Quality Management and Six Sigma could enhance the impact on employment by improving productivity, reducing rework, and so on, though even here new types of jobs in marketing, purchasing, service, and other functions may be created (Ishikawa \& Lu, 1985; Ohno, 1988)

\section{Labor and Loyalty}

Exacerbating the impact of globalization and technology on employment, skill-building, income disparities and stagnation, social mobility and cohesion, and political discourse, has been the process, which has unfolded over the past forty years, of making the American worker "disposable". This evocative label employed by Uchitelle(2006) for how labor is viewed by management and the majority of politicians in power brings into focus the lack of commitment and loyalty that firms feel toward their employees. Following the New Deal, through World War II, and into the 1960s, a period Goldin and Margo (1992) refer to as "The Great Compression" ensued. Income inequality declined and labor's share of national income rose to levels not seen before or since. The almost single-minded focus on returns to shareholders, with CEO salaries tied to this performance measure, has helped squeeze out consideration of other stakeholders, particularly employees. The ratio of CEO salary to that of the entry level worker in the Fortune 500 increased rapidly starting from a multiple of around 70 to 1 in the 1980 s to more than 250 to 1 in 2010, both magnifying income disparity as well as reducing any empathy top executives might have felt for workers on the lower rungs of their firms (Mishel \& Davis, 2014). The marginalization of the worker has been achieved by a coalition of financial institutions, business interests, powerful lobbyists, and cooperative politicians with minimal concern for the rights of employees (Brill, 2018). The author argues that the system has been rigged to benefit the protected few, leaving the majority to fend for themselves.

In addition to mutually reinforcing effects of technology, globalization, and the increasingly asymmetric employer-employee relationship, a fourth factor may have added to the rise in jobs/skills gaps, shrinking of middle income jobs, and increasing income inequality: the financialization of the American economy (Plys, 2014; Ernst, 2015). Financial engineering taken to its risky extremes brought devastation to the economies of much of the developed world in 2007 (Stiglitz, 2012). While securitization of debt, credit default swaps, hedge funds and the like have yielded high returns for some financial institutions, they have also increased the risks to shareholders and, indeed, to the economy as a whole (Admati \& Hellwig, 2013; Foroohar, 2018). Labor's share of income has dropped to its lowest level in over thirty years 
with the portion going to retained earnings, dividends, and executive salaries growing sharply (Dunhaupt, 2016), providing further evidence that financialization has had insidious effects not only on labor power but also on social mobility, income inequality, and funding the social safety net (Lin \& Tomaskovic-Devey, 2013; Entin, 2017).

\section{States and Impacts}

The four major forces interact with and influence one another making it almost impossible to figure out which specific pressure is responsible for a particular outcome. For instance, technology has sparked and stimulated the global dispersion of production, markets, knowledge, and financial activities. This, in turn, has stimulated further innovation in products and processes, developing new markets and profits abroad for TNCs, eliminating some jobs and creating others, diminishing labor power (particularly in the United States), with governments (both local and federal) often acting to contain union influence and actions. Financialization, driven by both technological developments and worldwide banking networks, has augmented the earnings of the wealthiest corporation and individuals, further marginalizing labor, widening income disparities, reducing social mobility, and engendering resentment towards the "elites", while polarizing society along the lines of identity politics (Stiglitz, 2012; Stewart, 2018; Cook, 2019).

In terms of economic performance, Western economies, though they have gone through the slow downs and recessions one might expect in capitalist societies, have maintained an average of 2-3\% in GDP growth over the past thirty years (WEF, 2015; CEIC data, 2017; Trading Economics, 2017). Despite this steady growth, their share of world output has shrunk from a dominant $75 \%$ in 1980 to around half that in 2015, mainly due to the rise of Asian economies, whose share has risen almost threefold (Barua, 2015). In the United States increase in income inequality and wage stagnation have become the new normal, accompanied by a shrinking of the middle-income population (Peck, 2011; Wisman, 2013). Rising health care costs, college education becoming less affordable, the displacement of workers due to the outsourcing of manufacturing and service jobs to low wage countries, the introduction of technologies which have eliminated/created/changed numerous occupations, the disproportionate wealth accruing to financial services firms, and the inability of working people to act to help themselves have created an atmosphere of extreme angst in sections of the population (Inglehart \& Pippa, 2016; Moffitt, 2016).

The perception that the United States (US) has been exploited by countries (which, as Werner (2018) notes, are accused of using the mantra of free trade to indulge in unfair practices) has fueled a potent antipathy to trade, a trend which seems to have led to a sharp drop in trade recently (WTO, 2019). There has been some research indicating that globalization did indeed result in the loss of over 4 million jobs in the US over the period 1999-2010, unlike in the preceding decade when around half that number of jobs had been created (Scott, 2015). As Chamberlain (2016) notes, even if employment shrinkage was indeed of the order of 5 million over a decade, it pales into insignificance compared to the normal churn in the job market which is in the range of nearly 30 million per year. In any event researchers have concluded that the bulk ( $80 \%$ or more) of the employment decline in the country is technology-related (Morrison Paul \& Siegel, 2010; Bowler, 2017; Mason \& Solis, 2017).

Not all segments of society have been adversely affected by the four forces of technology, 
globalization, labor's shrinking power, and financialization. Business firms have performed remarkably well, recovering, with some help from the government, from the downward spiral of 2007-2008. Corporate profits earned over the past decade total over $\$ 18$ trillion, resulting in a bonanza for shareholders (Statista, 2019), though there are early indications that corporate profits may have peaked The Economist, 2019(a). Financialization has worked both to enhance corporate profits as well as to reduce firms' dependence on labor (adding to the impact of technology-biased skill requirements and outsourcing of both production and services). The marginalization of labor has given rise to a rising level of hostility towards "elites" who are seen as willfully ignoring the needs of the working person, towards countries which are deemed responsible for taking jobs abroad, and towards immigrants who are viewed as both a security threat and home-grown competitors for jobs (Levitsky \& Ziblatt, 2018; Kuttner, 2019).

\section{Responses Implemented (R1)}

Among the positive impacts of the four forces working in tandem are:

- The availability, over a long period of time, of relatively inexpensive consumer goods in the US and the marginal rise in the Consumer Price Index between 1990 and 2018 (Statista, 2018)

- The optimization of manufacturing costs, lead times, quality, and operational flexibility through the creation of global value chains (Marcolin \& Squicciarini, 2017)

- The benefits accruing to TNCs of establishing R\&D facilities in developing nations (China, India, Brazil) with excellent, low cost human resources and the infrastructure for technology development (Fu, Pietrobelli, \& Soete, 2011)

- Steady economic growth in North America and the EU, despite the admission of less prosperous countries to the latter (Statista, 2019; Trading Economics, 2019)

- The adoption of a free market, free trade regimen in a majority of countries, which was part of the US-led effort to establish a stable geopolitical order (Statista, 2019).

These signs of rising prosperity appear to have been overshadowed by developments with adverse economic, political, social, and cultural repercussions (see the State/Impact box in Figure 1). Some of the negative impacts, as noted earlier are: reduced employment in low-skilled manufacturing jobs; an increase in low paid service occupations; declining intergenerational mobility; widening income disparities with the top $10 \%, 1 \%$, and $0.1 \%$ of income-earners progressively gaining exponentially more from economic expansion; hostility towards "elites" for not acting to remedy the situation; the attribution of negative developments to other countries (for not playing by the rules) or to foreigners (particularly immigrants); and the perception that the US has bartered away not only well-paid jobs, but also its technological competencies and competitive edge (Pollin, 2011; Piketty, 2014).

In what follows we review some of the actions which have been undertaken thus far to address the impact of the four forces acting in concert, generally tracking the elements listed in the Response section (R1) of Figure 1.

\subsection{External Intervention to Mitigate Employment Effects}

As the pace of outsourcing picked up, it became apparent that more external intervention than the limited efforts hitherto undertaken was required to facilitate the adjustment of workers to 
an environment in which new products, processes, and management innovations (such as lean manufacturing) combined with low wage manufacturing abroad had created a seismic shift in the nature of work and the job market. The federal government enacted the Work Improvement Act (WIA) in 1988, with Congress appropriating funds to be disbursed to state and local agencies to implement training both for first-time job seekers as well as for the involuntarily unemployed. After a quarter century of training youth for entry into the job market, people with disabilities, and adults looking to recover from being laid off, the results are not encouraging. In regard to entry level jobs, training appeared to make very little difference to hiring and retention, while in the case of factory workers, the success rate in finding work with no loss in income was equally disappointing (Global Markets Institute, 2016; Selingo, 2018). Mason and Solis (2017) observe that, while U.S. trade doubled over the forty years after 1970, social expenditure has declined in real terms contributing to the social and political consequences noted earlier.

It appears that the free market and free trade, as Fadulu (2018), McKissen (2018), and others poignantly observe, cannot self-adjust to the impact of the four interacting forces, and that federal job training and retraining programs have inbuilt structural flaws (centralized funding, uncoordinated decision-making; mismatch between skills of the future and skills taught, and little buy in from potential employers). Despite the best efforts of policy makers, technology and knowledge workers tend to congregate in already-thriving locations (clusters) rather than migrate to places which have fallen behind due to one or more of the four factors; (The Economist, 2017; Saunders, 2018; Porter, 2019)

\subsection{Stimulating New Business Creation}

One of the most reliable sources of employment in the United States has been entrepreneurial businesses. Typically, nearly eight out of ten jobs created have been through startups, though nearly half of these jobs vanish due to the high failure rate in the first year or two of a small business's existence (Henry, 2017; Mansfield, 2018). Unfortunately, the rate of entrepreneurial activity has plummeted by about $25 \%$ over the last four decades in this country almost paralleling, perhaps coincidentally, the decline in manufacturing's share of GDP and in employment (Buchanan, 2015, Casselman, 2017; Knox, 2017). The rise of advanced technology firms situated at the Information-Communication-Entertainment (ICE) nexus has created a demand for services (streaming, the internet of things, multifunction cell phones) which call for a higher order of technical skills, leading to the creation of a limited number of jobs at the high income end and many paying low wages. (Galloway, 2016; Zuboff, 2019)

Even when state support for entrepreneurs is made available, the resulting startups are often in advanced knowledge fields. This applies to the bulk of the federal investment of around \$220 million from 2003-2013 to support entrepreneurship in new or existing clusters (Chatterji, Glaeser, \& Kerr, 2013). State and local government facilitation of start ups has a similar outcome. Consider the Genius New York (2018) grants and competitions offering prizes and accelerator facilities for businesses related to drones in Central New York. Building on local capabilities, the intent is to create a cluster in the field. StartFast (2018), also in the same region of New York, serves as an accelerator for businesses from anywhere in the world, which then compete for funding. In both cases the business prospects are 
promising for the successful entrepreneurs, and though the direct employment potential is limited, the creation of viable ecosystems could create successful clusters of small and medium enterprises. Again, as in the case of skill-biased technology and employment, such interventions to foster entrepreneurship typically work best where supportive ecosystems already exist or are being actively promoted.

\subsection{Trade-Related Actions}

The most recent effort to address the perceived imbalance in trade and employment, and wage stagnation, has been the imposition of tariffs, initially on steel and aluminium, and later on a range of other products imported into the US. While such actions may have the immediate result of stimulating the industries being protected, the long term impact could be an increase in the prices of products dependent on global value chains, retaliatory tariffs reducing demand for American-made goods, a trade war which applies the brakes to worldwide economic growth, and a system of restricted trading which could constrain innovation and options for customers, raise prices, and adversely affect those most in need of help (Forbes, 2018; Marsh, 2018). It may be too early to evaluate the impacts of the tariffs imposed on China by the US and the Chinese retaliatory imposts. However, early indications are these actions have slowed down China's economy slightly while inflicting pain on many American firms and, possibly on consumers as well. The use of trade as a weapon in economic, political, and diplomatic affairs could gradually unravel the international order brokered over the past half century (The Economist, 2019(b)). Even worse, any globally-coordinated action on issues such as addressing climate change, terrorism, drug trafficking, and so on, could become less likely.

\subsection{Labor}

Efforts to unionize have been opposed by a variety of large employers like Amazon, Wal-mart, and other businesses in manufacturing and service industries (Kopytoff, 2014; Capital \& Main, 2013). Industry-based unions like that of restaurant workers have encountered stiff opposition from businesses and politicians. The increase in the number of 'right-to-work' states, the hostility towards raising the minimum wage, and an attempt to eviscerate public sector unions are all part and parcel of a concerted movement to erode workers' rights in this country (Bivens \& Shierholz, 2018). Paradoxically, as populist politicians rail against how policy makers and 'elites' have let the working class down, the effort to mute the voice of labor appears to be gaining more momentum. Meanwhile, the repercussions of technological change and a possible trade war could only make matters worse.

\subsection{Government Policies}

Scholars generally view the economic, social, and political policies adopted by a government as important shaping and controlling influences on capitalism (Stiglitz, 2012). We concur with this perspective. However, since we are discussing responses to the four factors, we briefly examine governmental responses in terms of policy changes implemented. We have already elaborated on efforts to foster entrepreneurship, undertake job (re)training, undermine the power of labor, impose tariffs to redress trade imbalances, enact tax cuts to (unsuccessfully) generate more investment, and so on. Among the government policies which may have exacerbated the situation are: 
- Low income housing being located far from potential employers

- The limited availability of public transport in smaller cities and towns

- School districts with low tax revenues falling farther behind the average

- The lack of support for early childhood education

- Health care being tied to employment

- Labeling workers as vendors, contractors, and so on thereby minimizing payment of benefits

- The rising cost of a college education, and the ballooning of student debt to over $\$ 1$ trillion.

- The reluctance to regulate predatory lending practices and the assumption of high risk by financial service firms, often at the expense of the tax payer.

As Stiglitz (2010), Piketty (2015), Chetty (2019), and others have noted, government policies can moderate the dysfunctional effects of capitalism. However, regardless of political affiliation, governmental actions in the US seem to have favored the wealthy. Income inequality has been magnified and social mobility has plunged to an alarming degree. The distrust of globalization and the (immigrant) Other, and resentment felt by lower and middle income individuals towards intellectual and financial elites has grown sharply over the past two decades (Frieden, 2017).

\section{Responses Proposed (R2)}

It is clear that the responses adopted have, by and large, been ineffective in addressing the negative outcomes of technology, globalization, financialization, and labor's marginalization.

In this section, we propose a set of initiatives and strategies aimed at addressing the persistent economic, social, and political imbalances and disruptions, which may actually become even worse in the years to come.

\subsection{Trade Imbalances}

To begin with, economic and political nationalism which appears to be behind some countries' recent actions (e.g. Britain's exit from the EU, imposition of tariffs by the US, China's declared intent to become a technological leader by 2025, the desire on the part of nations such as Turkey, the Philippines, India, and others to attain greater standing by silencing dissent) strikes at the heart of globalization by reducing interdependencies among nations through trade. The gradual unraveling of global supply chains is likely to adversely affect trade and economic growth sooner rather than later (The Economist, 2019c). This reversal of the post-war order could reduce cooperation among, and harmony within, nations, without achieving the goal of ameliorating the loss of jobs due to international trade. The reduced access to foreign suppliers, production, markets, technology, and creative ideas could overwhelm any initial gains from raising tariffs and assertions of unbending sovereignty. For instance, rather than impose tariffs on goods from China, the US could explore forming an alliance with various countries aimed at reducing the unfairness of the Chinese trade regimen (a variation of the TPP and the proposed U.S.-EU Trade Agreement combined (USTR, 2018; Amadeo, 2019). Such an alliance could also help contain the extent to which patent and copyright infringement in China and elsewhere erodes the technological advantage of 
innovation leaders.

\subsection{Financial Stability, Inequalities, Social Mobility}

The damage visited by the financial implosion of 2007 upon the economy of the United States (and, indeed, the economies of most other countries in an interconnected world) in terms of output, income, and employment was severe (Stiglitz, 2012). Drastic measures were necessary to rescue the financial system. While most of the banking behemoths have recovered to at least pre-crisis levels, the perception that the "elites" (a term which covers policy-makers, the wealthy, corporations, academics, most politicians) took care of their own while ignoring the plight of the middle-class persists. The appeal of populism may be attributed, in part, to this belief (Funky, Schularick, \& Trebesch, 2018). It would consequently seem imperative that all necessary steps be undertaken to avoid a repeat of 2007. There are, to be sure, processes and policies in place (higher equity requirements, periodic stress tests, governance oversight) which are aimed at preventing, or providing a warning of, an impending collapse (Linke, 2018). Moreover, the mortgage business is nowhere near as leveraged as it was around 2005. However, attempts are being made to deregulate the industry, the arguments being that the banks have learnt from their experiences and that regulations are constraining their ability to earn more profits. This is a perilous course of action if it leads to an increased use of taxpayer-backed deposits for risky bets, more short-term borrowing, loosening governance procedures, the sidelining of the Consumer Financial Protection Bureau, and so on (Lewis, 2014; Wolf, 2014; Pressman \& Scott, 2018). The link between financialization and income inequality has been conclusively established by scholars such as Lin and Tomaskovic-Devey (2013), making the need for regulation, or at least, no further deregulation, imperative.

\subsection{Technological Capabilities}

The trading of market access for technological information, is one of the reasons why TNCs based in technologically advanced nations have been gradually experiencing appropriation of their competitive advantage by companies based in countries with large markets. One approach to deal with this in advanced countries is to offer incentives (e.g. treat R\&D as an expense or make it tax deductible for five years; allow accelerated depreciation for investments) to companies who invest in industries central to technological leadership. Again, this would be viewed as picking winners and losers, but in order to counter China's full-fledged (and the German, French and other countries' more moderate) technological 'state capitalism', the US needs to take a firm stand to reverse an eroding technological edge (Naughton \& Tsai, 2015; The Economist, 2018b).

We advocate going beyond offering incentives and subsidies by crafting a National Innovation System of the variety adopted by many European countries, and deployed by countries like China, India, and Brazil with active governmental intervention (Kaakonsson \& Slepnov, 2018; Sesay, Tulin, \& Wang, 2018). We are not arguing for a government-led effort (as in China) to maintain the US's position of technological leadership. However, the facilitation of innovation in high knowledge and technology industries (KTI) and even more particularly in medium-high KTI (in which the US seems to be losing ground) would seem imperative (NSF, 2018). As the US continues to spend less on R\&D while countries like India and China increase their outlays (China now invests almost as much in R\&D as does the US), 


\section{$\triangle$ Macrothink}

and adopts a relatively laissez faire approach to innovation, other countries might continue to narrow the technological gap (World Bank, 2016).

It might also help if investment were to be stimulated in industries in which manufacturing would have to be carried out in the US (wind turbines, battery charging stations, for instance), further encouraging such businesses to commit resources by making the R\&D expenses they incur tax deductible.

\subsection{Job Training}

It is imperative to reinvigorate, and craft a new approach to, job training for first-time and experienced job seekers, and to involve corporations in the effort, not just as funders but as participants. While a policy such as the one adopted in Germany (with eligibility for college decided by performance in secondary school, those not deemed suited for college being placed in apprenticeship programs (Walden \& Trotsch, 2011)), is not likely to be accepted in the US, some variation of this approach might be worth considering. For instance, firms could offer paid internships for a few months, or pay part of an individual's wages for a year (the rest being borne by the state/federal government) while training is completed at a 'skilling/reskilling center'. An "apprenticeship" program such as the one proposed by the US government (Varas \& Iovine, 2017) could be strengthened if firms commit to employ the "apprentice" after the training period is over. This might help ensure the employer is involved in the content and method of learning. While existing job training centers, and communityand certain four-year colleges might be appropriate partners for this sort of public-private partnership, corporate investment in equipment, curriculum design, training of instructors, and so on, would be essential. In the case of industries facing long term decline, (say, coal mining), the European approach of a public-private partnership with funding provided by the industry and federal/state governments might be worth considering (Zaffos, 2016). Despite their relative weakness in the U.S., unions would be valuable partners in helping decide the purpose and content of training/retraining programs well before an industry's downward trajectory accelerates (Hanks \& Madland, 2018). The evidence, however, suggests that both governments and corporations in the U.S. are whittling away at the already-diminished power of labor. Recent court decisions have accentuated this decline (Paarlberg, 2018). Such a trend does not bode well for workers as they face the threats posed by technological change, globalization, and financialization. There are a few signs of a slight resurgence in unions in industries such as restaurant/food services, education, and so on (Bernstein, 2017), indicating, perhaps, that a bottom-up approach to engaging in collective bargaining might emerge to deal with the rising intensity of challenges facing the work force of today. Workers in low paid service jobs in some industries are seeing a gradual movement towards collective action (Time, 2019). However, employees at the lower rungs of high tech business are being actively discouraged from organizing. Google, Facebook, Uber, Airbnb, and other such firms have hired thousands of people as temporary workers, contractors or vendors, which gives them few rights. Even mid-level employees of these firms are made aware, through coercion and even retribution, of their employers' anti-union stance (Charpentrat, 2018)

\subsection{Government Policies}

Governments, regardless of which party is in power in the U.S. (and, for that matter, in most other countries) tend to favor policies which lead to economic growth, rising incomes, and 
low unemployment. While this approach tends to meet with widespread approval, the accretion of most of the economic gains to the highest income earners, and the reduction of social support for the poor and historically disadvantaged, has only enhanced the negative impacts of the four factors (Porter, 2015). Education, particularly early childhood, and primary and secondary, are areas in which governmental investment can pay for itself many times over, though it may be argued that income inequality is the cause and educational deficiency one of the many symptoms (Porter, 2015; Hanauer, 2019). Reducing the burden of debt incurred by college students, and making health care available to all (not just through employment) would create more stability and reduce the uncertainty that many people experience hanging over them. Far from providing an incentive to them to work harder, the arduous conditions induce many to give up (Bureau of Labor Statistics, 2011; Griffin, 2018). The situation could degenerate in the coming years, as new, ever-more disruptive technologies become an ubiquitous part of everyday life.

The long term interests of the United States have not been well served by its economic policies either. For instance, upgrading of infrastructure (highways, airports, mass transit, telecommunications, high speed internet, and so on) has been much talked about with little action (Stiglitz, 2012). Investment in science, the basis for most technological developments in the past, has gradually gone down (Brynjolfsson \& McAfee, 2014). The likelihood that the US will be the technological leader in the $21^{\text {st }}$ century has diminished considerably as other countries (notably China) are rapidly expanding their outlays on scientific research. The skepticism evinced by many national leaders towards research findings in fields such as climate change tends to diminish respect for science and scientists, resulting in even less interest in the discipline among young people.

Rolling back regulations in various industries opens up new opportunities for businesses, but could, in the long term endanger public health. It could also mean that the US might fail to cash in on some industries of the future e.g. renewable energies, electric cars, substitutes for metals such as steel and aluminium, and so on.

The use of tax cuts as a tool to enhance growth might work in the short run, but government policies that do not take into account the long term challenges the country faces due to rapid technological change risk dragging the country down not only in terms of increasing disparities in society but also in economic metrics. Given the political polarization prevalent in the country, the potential for bipartisan agreement on economic and social policies seems slim. Corporations, though often accused of being responsible for many of the country's ills have to play a major role in redressing the dysfunctional outcomes unleashed by the four forces. Business firms have a lot to lose from instability and uncertainty in societies of which they are a part, and must shoulder greater responsibility for preserving societal sustainability.

\subsection{CSR and Employment}

The debate over Corporate Social Responsibility (CSR) has continued over more than half a century. Few companies now hew to the Friedman (1970) school of thought that firms, by earning a profit, discharge their economic responsibilities which directly and indirectly benefit society. Most firms now hew to the belief that they should avoid doing anything that harms society and, in fact, should act in a way that creates positive outcomes for society or segments thereof (Moody-Stuart, 2014). 


\section{Macrothink}

The arenas in which CSR is most commonly deployed are the community, market, and employees. Community CSR includes support extended to causes benefiting societies at large in fields such as health, education, human rights, etc. Market CSR is directed to leveraging the firm's core competencies to benefiting disadvantaged groups, in line with Porter and Kramer's (2006) shared-value approach (e.g. firms specializing in job training which provide free services in teaching unemployed workers new skills; computers donated to schools by information technology firms). Employee CSR in essence is focused on improving working conditions (safety, child care, work-life balance), ensuring workers' rights (gender rights, freedom from discrimination), treating employees with respect, retraining them, and so on (Moon, 2014; Williams, 2014). We suggest that business firms, especially those with record levels of profits (such as the Silicon Valley and Seattle giants) invest a fraction of those earnings in ensuring the continued stability of the diverse stakeholders in the societies which have been the launch pads for their success. Focusing on community wellbeing by enhancing the capabilities and skills of present and potential employees would be an effective way to deal with a worsening employment situation (Osterman, 2006; Graham, 2017). Even thorny issues such as education (from funding and organizing early childhood, skill-and-liberal-arts-based, vocational, and college), health care, equal treatment of women and minorities, and other such social concerns, are worthy areas for corporations to invest, and get involved, in. Alliances with governments, NGOs, Social Entrepreneurs, and other such agents would help, but if they are really serious about CSR and can see that their futures are wrapped up in those of the societies they call home, business firms must leave the sidelines and be part of the fray (Schwab, 2008; Tyson, 2013).

With the rise in the pace of product and process innovation, it becomes almost imperative that companies recognize that CSR begins at home. That is, as product and process innovation lead inexorably to new, hitherto unknown technologies requiring radically different skill-sets from the ones possessed by some or many existing workers, it is incumbent on management to take responsibility for these employees' work place security and on-the-job fulfilment. For instance, as new forms of technology make their appearance, firms should not only develop strategies to profit from the emerging market opportunities, they should simultaneously formulate plans to re-skill employees to transition to the new technology. In a similar fashion, as new methods are developed to raise productivity in the work place (e.g. through automation and robotics), depending on the free market or governments to take care of displaced workers has been, by and large, less than adequate. It is time for corporations to play an expanded role in dealing with the changes sweeping society, changes which they have a played a leading role in effecting. Microsoft (2017) has taken a step in this direction by forming an alliance with the Markle Foundation and investing \$25.8 million to help workers acquire the digital skills they will need in the workplace of the future. The Royal Bank of Canada has invested over $\$ 500$ million in a multiyear project to prepare youth for the world of work in 2025. Features of this initiative are the involvement of young people in envisioning what they need to prepare for, as well the use of metrics to assess accuracy of predictions and effectiveness of the action plans (RBC, 2018). Other companies such as AT\&T, Apple, and Google, and IBM have also launched similar initiatives which stand at the confluence of community-, employee- and market-driven CSR. AT\&T provides a particularly 


\section{Macrothink}

striking example of a firm which has embarked on a revolutionary strategy to retrain its employees. After finding that nearly half its 250,000 employees lacked the necessary competencies to meet the company's digital needs over the next decade (and that many specializing in hardware would be rendered redundant), AT\&T has launched a massive retraining program for its employees investing $\$ 1$ billion in the effort. The rationale underlying this strategy is partly that hiring and training new employees would cost more, but the main reason appears to be that a long term, ongoing relationship with its own employees would both bolster morale and foster mutual loyalty (Caminiti, 2018). Google, in alliance with Coursera, is offering an IT certificate course to be completed in about six months and a non-profit called Per Schola has successfully equipped many women and minorities to find rewarding jobs in the digital economy (Wired, 2018). However, the costs of these types of programs typically put them beyond the reach of individuals to fund themselves. Considering that a majority of executives in firms with revenues over $\$ 100$ million believe that more than $25 \%$ of all existing jobs will be disrupted by 2025 , drastic action is required. In the same survey of executives (Ilanes et al., 2018) about $60 \%$ of executives believe that corporations should take the lead in addressing this potential disruption. Fully one third of those surveyed were of the belief that the looming jobs-skills gap is one of the top five priority issues for businesses to address urgently.

A distinction has been made by scholars such as Carrasco, Saorin, and Osma (2016) between Core and Supplementary CSR, the former being rooted in the firm's core competence and flowing from the firm's strategy. Supplementary CSR, on the other hand, would not necessarily stem from the business's intrinsic capabilities. We contend that employee CSR aimed at re-skilling employees to adjust to a shifting core competence and strategic direction, is, in fact, a Core CSR activity resulting in minimal internal disruption, more effective strategy implementation, and improved performance.

\section{Discussion and Conclusion}

\subsection{A Brief Synopsis, Limitations, and Possible Directions}

The conceptual model developed in this paper draws from various strands of the literature and seeks to provide an analytical, action-oriented framework to deal with the complex challenges which developed nations such as the US face today. Among the problems that call for solutions are a decline in the number of well-paid manufacturing jobs, an insufficiency of highly skilled workers, rising income and social inequalities, falling intergenerational mobility, the diminishing share of labor in national income while corporate profits and shareholder returns move upwards, a heightened opposition to international trade, and a resurgence of nationalism and distrust of the Other. In proposing what needs to be done, we argue that government policies and corporate strategies need to work in tandem to deal with the threats to economic, political, and social stability. The relationship between governments at all levels and corporations should be neither antagonistic (where government is seen as curbing firms and innovative processes) nor permissive (where governments are, in effect, "captured" by business through lobbying, election-funding, and so on). Rather the relationship should be collaborative based on the recognition that the very nature, perhaps existence, of their society and way of life may well depend on pursuing mutually beneficial strategies. Clearly, the four factors, resultant states, and suggested responses are, by no means, 
exhaustive. Other factors, such as demographics (median age, educational level, and so on), and other outcomes and actions taken could be added to the list. One direction for future work in this field would be to use available measures for technological advances, globalization, labor's influence, and financialization to determine their relationship to the outcomes or states. The slowdown in world trade currently under way offers a rare opportunity to study the impact of declining globalization on the various states listed in Fig. 1. Accelerations in technological change may be similarly investigated insofar as their impacts on inequality, employment, political uncertainty, and other such outcomes are concerned.

\subsection{The Future-An Even Greater Imperative to Act Now}

The involvement of corporations has become all the more imperative since the technologies being developed by big tech firms (e.g. Google, Facebook, Amazon, Microsoft, Apple, and others) could have repercussions which are an order of magnitude higher than anything that went before.

In addressing the workplace impact of technological change, Husain (2017) notes that the internet of things (IoTs) has progressed from monitoring to taking action to formulating goals (e.g. from tracking cardiac function, to recommending medications, to prioritizing quality of life over longevity). IoTs are now morphing into artificial narrow intelligence (ANI) based on deep learning (focused on goals set by humans, such as drone deliveries, autonomous cars, stock trading). As ANI becomes a taken-for-granted part of our lives, the nature and availability of work will shift radically (Brynjolfsson \& McAfee, 2014). In the near term the social, cultural, and political impacts of innovations are likely to rival the environmental impact, concerns over which have elicited widespread alarm and received wide publicity. The need for corporations to act has never been so vital or imperative.

An expansive view of CSR becomes a pressing strategic priority when we reflect on the societal transformations that could face us in the next twenty to thirty years. The rapid introduction of new technologies could cause social upheaval. Though some authors like Gordon (2016) and Dickson (2017) posit that ANI and automation may not create mass unemployment as is widely feared (by creating complementary jobs and those requiring personalized service), a study by the McKinsey Global Institute (2017) concludes that, by 2030 , nearly $40 \%$ of jobs in the US and Europe, $20 \%$ in China, and about $15 \%$ in India could be at stake, even after accounting for the ancillary employment that will be created. Other authors such as Rotman (2013), McClelland (2018), and West (2018) view this outcome as quite likely, though there is general agreement that routine tasks requiring limited cognitive skills are likely to be automated first. Indications are that the combination of big data and ANI could displace millions of white- and blue-collar workers worldwide in occupations as diverse as medicine and health care, stock selection, the legal profession, education, truck driving, customer service, and so on (Computer Weekly, 2018).

The broader impact of ANI on society is also of some concern. For instance, Harari (2018) posits that ANI stimulates a trend toward greater centralization of data and decision-making. The consequent concentration of power could further threaten social and political stability, and create even more disparities. Coupled with lower college graduation rates and the ever-rising cost of education, timely action by governments and corporations is essential to counter the multiple negative fallouts of technological change both in the workplace and in 
society at large. The onus rests on the organizations leveraging the four forces (technological change, global expansion, labor power, and financialization) to consider, at an early stage, more than the market and profit implications of their strategies. The technologies of tomorrow are, unlike most innovations in the past, not likely to create new tasks as numerous, or at the same or higher income levels. As part of their CSR regimen, a careful audit of how their creations will impact society in general and the world of work in particular, ought to be undertaken by firms at the forefront of technological advancement. By viewing markets, employees, and communities from a holistic perspective, and integrating reduction of negative impacts on stakeholders into their CSR strategies, corporations would serve their own long-term interests as well as those of the societies in which they operate..

\section{References}

Admati, A., \& Hellwig, M. (2013). The Bankers' New Clothes. Princeton: Princeton University Press. https://doi.org/10.1515/9781400851195

Amadeo, K. (2019). Trans-Pacific Partnership Summary, Pros and Cons Retrieved from https://www.thebalance.com/what-is-the-trans-pacific-partnership-3305581

Applebaum, A. (2018). A warning from Europe. The Atlantic, 53-63.

Arthur, B. (2009). The Nature of Technology: What it is and how it evolves. New York: Simon and Schuster

Barua, A. (2015). Packing a mightier punch: Asia's economic growth among global markets continues. Retrieved from https://www2.deloitte.com/insights/us/en/economy/asia-pacific -economic-outlook/2016/q1-asia-economic-growth-continues.html

Bernstein, J. (2017). Bend the Trend: Reviving Unionization in America. Retrieved from https:/www.washingtonpost.com/news/posteverything/wp/2017/08/24/bend-the-trend-revivin g-unionization-in-america/?noredirect $=$ on\&utm_term $=.7 \mathrm{e} 6 \mathrm{e} 485 \mathrm{~b} 57 \mathrm{e} 5$

Bhagwati, J. (2007). In Defense of Globalization. Oxford: Oxford University Press.

Bivens, J., \& Shierholz, H. (2018). What Labor market Changes have generated Inequality and Wage Suppression? Economic Policy Institute.

Bowler, T. (2017). Will globalization take away your job? BBC New.

Brynjolfsson, B., \& McAfee, A. (2014). The Second Machine Age. New York: W. W. Norton.

Buchanan, L. (2015). Retrieved from https://www.inc.com/magazine/201505/leigh\%5Cbuchanan/the \%5C-vanishing\%5C-startups \%5C-in\%5C-decline.html

Brill, S. (2018). How Baby Boomers Broke America. Time.

Bureau of Labor Statistics. (2011). Retrieved from https:/www.bls.gov/opub/btn/archive/ how-long-before-the-unemployed-find-jobs-or-quit-looking-pdf.pdf

Caminiti, S. (2018). Retraining nearly half the workforce. Retrieved from https://www.cnbc.com/2018/03/13/atts-1-billion-gambit-retraining-nearly-half-its-workforce. html -the-trade-war-with-china/\#4de547b9b2d20

Campbell, J. (2013). Becoming Techno-Industrial Power: Chinese Science and Technology Policy, Issues in Technology Innovation, Center for Technology at Brookings.

Capital \& Main. (2013). Walmart's war against Unions and the U.S. Laws that make it possible. Retrieved from https://capitalandmain.com/walmarts-war-against-unions-and-the- 
u-s-laws-that-make-it-possible

Carrasco, Saorin, \& Osma. (2016). The Illusion of CSR: drawing the line between core and supplementary CSR, Sustainability Accounting. Management and Policy Journal, 7(1), 125-151. https://doi.org/10.1108/SAMPJ-12-2014-0083

Casselman, B. (2017). Retrieved from https://www.nytimes.com/2017/09/20/business/ economy/startup-business.html

CEIC data. (2017). Retrieved from https://www.ceicdata.com/en/indicator/european-union/ real-gdp-growth

Chamberlain, A. (2016). Jobs created, jobs destroyed. Retrieved from https://www.glassdoor. com/research/jobs-created-jobs-destroyed-what-to-watch-in-fridays-jobs-report/

Charpentrat, J. (2018). Labor Unions face hard road in Silicon Valley. Retrieved from https://phys.org/news/2018-04-labor-unions-hard-road-silicon.html

Chatterji, A., Glaeser, E., \& Kerr, W. (2013). Clusters of Entrepreneurship and Innovation, Innovation Policy and Economic Forum, April. https://doi.org/10.3386/w19013

Computerweekly. (2017). How Automation Will Affect the IT Skills Gap, July, pp. 19-21.

Condliffe, J. (2019). Amazon's workers hate robots, The New York Times, July 22.

Cook, G. (2019). Raj Chetty's American Dream, The Atlantic, August.

Cui, X., Chen, B., \& Chang, Y. (2017). Transnational R\&D Centers and National Innovation Systems in Host Countries: Empirical Evidence from China. Canadian Public Policy, April, S107-121. https://doi.org/10.3138/cpp.2016-075

Dickson, B. (2017). Artificial Intelligence Creates New Job Opportunities, PC Magazine Digital Edition.

Djankov, S., \& Saliola, F. (2019). The Changing Nature of Work. Journal of International Affairs, 72(1).

Dunhaupt, P. (2016). Determinants of labor's income share in the era of financialization. Cambridge Journal of Economics, 41(1), 283-306. https://doi.org/10.1093/cje/bew023

Elms, D., \& Low, P. (2013). Global Value Chains, World Trade Organization.

Entin, S. (2017). Retrieved from https://taxfoundation.org/labor-bears-corporate-tax/

Epstein, D. (2011). Investment in Education Powers U.S. Competitiveness. Retrieved from https://www.americanprogress.org/issues/education-k-12/reports/2011/09/06/10376/investing -in-education-powers-u-s-competitiveness/

Ernst, E. (2015). The Shrinking Middle. Finance and Development, 20-23.

Fadulu, L. (2018). Why is the U.S. so bad at Worker Retraining? The Atlantic.

Fensom, A. (2018). Asia to stay World's Fastest Growing Region through 2030. The Diplomat.

Financial Times. (2016). Most manufacturing jobs lost due to technology, not trade. Retrieved from https://www.ft.com/content/dec677c0-b7e6-11e6-ba85-95d1533d9a62

Forbes. (2018). The dangerous myth the U.S. is winning. Retrieved from https:/www.forbes.com/sites/harrybroadman/2018/08/04/the-dangerous-myth-theus-is-winng Foroohar, R. (2016). The Myth of Financial Reform. Time, 23, 31-39. 


\section{Macrothink

Frieden, J. (2017). The politics of the globalization backlash: Sources and Implications. https://doi.org/10.2139/ssrn.3355610

Fu, X., Pietrobelli, C., \& Soete, L. (2011). The role of Foreign Technology and Indigenous Innovation in the Emerging Economies: Technological Change and Catching-up. World Development, 39(7), 1204-1212. https://doi.org/10.1016/j.worlddev.2010.05.009

Funky, M., Schularick, M., \& Trebesch, C. (2018). The Financial Crisis is still empowering far right populists: Why the effects haven't faded Retrieved from https://www.foreignaffairs.com/articles/2018-09-13/financial-crisis-still-empowering-far-righ t-populists.

Galbraith, J. (2012). Inequality and Instability: A Study of the World Economy just before the Great Crisis. New York: Oxford University Press. https://doi.org/10.1093/acprof:osobl/ 9780199855650.001 .0001

Galloway, S. (2017). The Four: The Hidden DNA of Amazon, Apple, Facebook, and Google. New York: Portfolio/Penguin

Genius, N. Y. (2019). www.geniusny.com

Global Markets Institute. (2016), Narrowing the Jobs Gap: overcoming impediments to investing in people. July, 1-42.

Goldin, C., \& Margo, R. (1992). The Great Compression: The Wage Structure in the United States at mid-century. Quarterly Journal of Economics, 107, 1-34. https://doi.org/10.2307/ 2118322

Gordon, R. (2016). The Rise and Fall of American Growth. Princeton: Princeton University Press. https://doi.org/10.1515/9781400873302

Graham, R. (2017). The Retraining Paradox. New York Times Magazine.

Guthrie, D. (2012). China and Globalization: The Social, Economic, and Political Transformation of Chinese Society. NY: Routledge. https://doi.org/10.4324/9780203121450

Genius New York. (2018). Retrieved from www.geniusny.net

Ghemawat, P. (2007). It's a semi-globalized world. The Globalist.

Griffin, R. (2018). Retrieved from https://www.bloomberg.com/news/articles/2018-10-17/ the-student-loan-debt-crisis-is-about-to-get-worse

Hanks, A., \& Madland, D. (2018). Better training and better jobs. Retrieved from https://www.americanprogress.org/issues/economy/reports/2018/02/22/447115/better-training -better-jobs/

Hughes, T. (1983). Networks of Power: Electrification in Western Society 1880-1930. Baltimore, MD: Johns Hopkins University Press.

Hanauer, N. (2019). Education Isn't Enough. The Atlantic.

Harari, Y. (2018). Why Technology Favors Tyranny. The Atlantic.

Harris, J. (2015). Globalization, Technology, and the Transnational Capitalist Class. Foresight, 17(2), 194-207. https://doi.org/10.1108/FS-03-2014-0016

Heater, B. (2017). Retrieved from https:/techcrunch.com/2017/03/26/technology-is-killingjobs-and-only-technology-can-save-them/ 


\section{Macrothink}

Henry, P. (2017). https://www.entrepreneur.com/article/288769

Husain, A. (2017). The Sentient Machine: The Coming Age of Artificial Intelligence. New York: Scribner.

Ilanes, P., Mourshed, M., Rutherford, S., \& Tyreman, M. (2018). Retraining and reskilling workers in the age of automation. McKinsey Global Institute.

Inglehart, R., \& Pippa, N. (2016). Trump, Brexit, and the Rise of Populism: Economic Have-nots and Cultural Backlash. HKS Working Paper RWP20-16. https://doi.org/10.2139/ ssrn.2818659

Ishikawa, K., \& Lu, D. (1985). Total Quality Control. Englewood Cliffs, N.J.: Prentice-Hall Izaak, R. (2008). The Globalization Gap: How the Rich get Richer and the Poor get further left behind. Upper Saddle River, N.J.: Prentice-Hall.

Kaya, Y. (2010). Globalization and Industrialization in 64 developing countries. Social Forces, 88(3), 1153-1182. https://doi.org/10.1353/sof.0.0300

Knox, R. (2017). The Hunt for an Entrepreneurial Ecosystem. The Kauffman Foundation's Ecosystem Model for Entrepreneurs-City Lab.

Kopytoff, V. (2014). How Amazon crushed the Union Movement. Retrieved from http://time.com/956/how-amazon-crushed-the-union-movement/

Kuttner, R. (2019). Can Democracy Survive Global Capitalism? New York: W.W. Norton. Levitsky, S., \& Ziblatt, D. (2018). How Democracies Die. New York: Crown Publishing Lin, K., \& Tomaskovic-Devey, D. (2013). Financialization and U.S. Income Inequality, 1970-2008. American Journal of Sociology, 118(5), 1284-1329. https://doi.org/10.1086/ 669499

Linke, R. (2018). How effective are post-financial crisis bank regulations? Retrieved from https://mitsloan.mit.edu/ideas-made-to-matter/how-effective-are-post-financial-crisis-bank-re gulations

Mansfield, M. (2018). Retrieved from https://smallbiztrends.com/2016/11/startup-statisticssmall-business.html

Marcolin, L., \& Squicciarini, M. (2017). Investing in innovation and skills: Thriving in global value chains, OECD Science, Technology and Industry Policy Papers, No. 44, OECD Publishing, Paris.

Marcus, A., \& Segal, H. (2018). Technology in America: A Brief History. London: Macmillan. https://doi.org/10.1057/978-1-137-33487-9

Marsh, K. (2018). U.S. businesses are beginning to pay the price for Trump's trade war. Retrieved from https://www.forbes.com/sites/kevinomarah/2018/07/27/trump-on-trade-allthe-wrong-moves/\#73f02cca2a80

Mason, J., \& Solis, M. (2017). Globalization on the cheap: Why the U.S. lost its way on trade. Brookings Institution.

McClelland, C. (2018). Retrieved from https://www.iotforall.com/impact-of-artificialintelligence-job-losses/

McKinsey Global Institute. (2017). Technology, Jobs, and the future of work. 
McKissen, D. (2018). My father-in-law won't become a coder no matter what economists say https://www.cnbc.com/2017/07/19/technology-gains-wont-make-up-for-these-job-losses-com mentary.html

Microsoft. (2017). Retrieved from https://news.microsoft.com/2017/06/27/the-marklefoundation-and-microsoft-partner-to-accelerate-a-skills-based-labor-market-for-the-digital-ec onomy/

Mishel, L., \& Davis, A. (2014). CEO Pay Continues to Rise as Typical Workers are paid less, Economic Policy Institute, Issue Brief \#380, June 12.

Moffitt, B. (2016). The Global Rise of Populism: Performance, Political Style, and Representation. Stanford: Stanford University Press. https://doi.org/10.11126/stanford/ 9780804796132.001.0001

Mokyr, J., Vickers, C., \& Ziebarth, N. (2015). The History of Economic Anxiety and the Future of Economic Growth: Is This Time Different? Journal of Economic Perspectives, 29(5), 31-50. https://doi.org/10.1257/jep.29.3.31

Moody-Stuart, M. (2014). Responsible Leadership: Lessons from the Front Lines of Sustainability and Ethics. Austin, TX: Greenleaf.

Moon, J. (2014). Corporate Social Responsibility: A Very Short Introduction. Oxford: Oxford University Press. https://doi.org/10.1093/actrade/9780199671816.001.0001

Morrison Paul, C., \& Siegel, D. (2001). The Impacts of Technology, Trade, and Outsourcing on Employment and Labor Composition. Scandinavian Journal of Economics, 103(2), 241-264. https://doi.org/10.1111/1467-9442.00243

Naughton, B., \& Tsai, K. (2015). State Capitalism, Institutional Adaptation, and the Chinese Miracle. Cambridge: Cambridge University Press. https://doi.org/10.1017/CBO9781139 962858

NSF. (2018). Knowledge and Technology-Intensive Economic Activity. Retrieved from https:/www.nsf.gov/statistics/2018/nsb20181/report/sections/overview/knowledge--and-tech nology-intensive-economic-activity

OECD. (1998). Towards Sustainable Development: Environmental Indicators. Paris:OECD.

Ohno, T. (1988). Toyota Production System: Beyond Large Scale Production. Cambridge, MA: Productivity Press.

Osterman, P. (2006). Community Organizing and Employee Representation. British Journal of Industrial Relations, 44(4), 629-649. https://doi.org/10.1111/j.1467-8543.2006.00517.x

Paarlberg, M. (2018). Retrieved from https://www.theguardian.com/commentisfree/2018/feb/ 26/janus-afscme-supreme-court-case-labor-unions-impact

Parmar, I. (2017). Elites and American Power in an era of anti-elitism. International Politics, 54(3), 255-259. https://doi.org/10.1057/s41311-017-0036-x

Peck, D. (2011). Can the Middle Class be saved? Retrieved from https://norek.pw/can _the_middle_class_be.pdf

Piketty, T. (2014). Capital in the Twenty First Century. Boston: Harvard University Press. https://doi.org/10.4159/9780674369542

Pissourios, I. (2013). An interdisciplinary study on indicators: A comparative review of 
quality-of-life, macroeconomic, environmental, welfare, and sustainability indicators. Ecological indicators, 34, 420-427. https://doi.org/10.1016/j.ecolind.2013.06.008

Plys, K. (2014). Financialization, Crisis, and the Development of Capitalism in the U.S.A. World Review of Political Economy, 24-44. https://doi.org/10.13169/worlrevipoliecon. 5.1.0024

Pollin, R. (2011). Economic Prospects: Can we please stop blaming Immigrants? https://doi.org/10.4179/NLF.201.0000013

Porter, E. (2015). Education gap between rich and poor is growing wider. Retrieved from https:/www.nytimes.com/2015/09/23/business/economy/education-gap-between-rich-and-po or-is-growing-wider.html

Porter, E. (2019). A Bigger Gap for Not-So-Big Cities. The New York Times.

Porter, M., \& Kramer, M. (2011). Creating shared value. Harvard Business Review.

Pressman, S., \& Scott, T. (2018). Ten years after the crisis: a lost decade. Real-world Economics Review, 83, 2-19.

RBC. (2017). Empowering the Youth of Today for the Jobs of Tomorrow. Retrieved from https://www.rbc.com/dms/enterprise/futurelaunch/about.html

Rotman, D. (2013). How Technology Is Destroying Jobs. MIT Technology Review Magazine, July/Aug.

Rubin, J. (2018). Retrieved from https:/www.washingtonpost.com/blogs/right-turn/ $\mathrm{wp} / 2018 / 02 / 08 /$ inconvenient-facts-about-the-tax-cut/?noredirect $=$ on\&utm_term $=.6 \mathrm{ce} 7 \mathrm{a} 91 \mathrm{~b} 40$ $8 b$

Sahoo, P., Dash, R., \& Nataraj, G. (2010). Infrastructure Development and Economic Growth in China, Institute of Developing Economies, Discussion Paper 261, October.

Startfast. (2018). Retrieved from https://startfast.net/

Saunders, P. (2018). The Evolution of the Creative Class. Retrieved from https://www.forbes.com/sites/petesaunders1/2017/05/04/the-evolution-of-the-creative-class/\# $37 f 1 f 8 \mathrm{e} 012 \mathrm{ee}$

Schwab, K. (2008). Global Corporate Citizenship. Retrieved from https://www.foreignaffairs.com/articles/2008-01-01/global-corporate-citizenship

Scott, R. Manufacturing Job losses. Retrieved from https://www.epi.org/publication/manufacturing-job-loss-trade-not-productivity-is-the-culprit/ Selingo, J. (2018). The False promise of Worker Retraining. The Atlantic.

Startfast. (2019). Startfast.net

Statista (2019). Retrieved from https://www.statista.com/statistics/222130/annual-corporateprofits-in-the-us/

Statista. (2018). Retrieved from https://www.statista.com/statistics/190974/unadjustedconsumer-price-index-of-all-urban-consumers-in-the-us-since-1992/

Statista. (2019). Retrieved from https:/www.statista.com/statistics/188165/annual-gdpgrowth-of-the-united-states-since-1990/

Steger, M. (2017). Globalization: A Very Short Introduction. Oxford: Oxford University Press. 
https://doi.org/10.1093/actrade/9780198779551.001.0001

Stewart, E. (2018). Corporate stock buybacks are booming thanks to the Republican tax cuts. Retrieved from https://www.vox.com/policy-and-politics/2018/3/22/17144870/stockbuybacks-republican-tax-cuts

Steyngart, G. (2008). The War for Wealth. New York: McGraw-Hill.

Stiglitz, J. (2006). Making Globalization Work, New York: Norton.

Stiglitz, J. (2012). The price of Inequality: How Today's Society Endangers Our Future. New York: W.W. Norton

Sutton, A. (2011). What is the importance of Early Childhood Education? Retrieved from https://www.livestrong.com/article/231407-what-is-the-meaning-of-early-childhood-educatio $\mathrm{n} /$

The Aspen Institute. (2018). Retrieved from http://www.skilledtradesplaybook.org/ partnering-community-colleges

The Economist. (2017). In the lurch. Oct. 21, 21-25.

The Economist. (2018a). How Democracy Dies, June 16, p. 8

The Economist. (2018b). Is China's growth model a threat to free market economics? June 13.

The Economist. (2019a). A slow unraveling, July 13.

The Economist. (2019b). America First Trade Policy: Bully for you, June 8.

The Economist. (2019c). Soaring stockmarket, peaking profits, July 20.

Time. (2019). When Human become Robots, July 29.

Trading Economics. (2017). https://tradingeconomics.com/united-states/gdp-growth-annual

Trading Economics. (2019). Retrieved from https://tradingeconomics.com/europeanunion/gdp-annual-growth-rate

Tyson, L. (2013). Retrieved from https://www.weforum.org/agenda/2013/11/what-roleshould-businesses-play-in-society/

Uchitelle, R. (2006). The Disposable American. New York: Knopf

USTR. (2018). The U.S.-EU Trade Agreement Negotiations. Retrieved from https:/ustr.gov/countries-regions/europe-middle-east/europe/european-union/us-eu-trade-agre ement-negotiations

Vachon, T., Wallace, M., \& Hyde, A. (2016). Union Decline in a Neo-liberal age: Globalization, Financialization, European Integration, and Union Density in 18 Affluent Democracies, Socius: Sociological Development for Dynamic World, July 11. https://doi.org/10.1177/2378023116656847

Varas, J., \& Iovine, A. (2017). The State of Federal Worker Training Programs. Retrieved from https:/www.americanactionforum.org/research/state-federal-worker-training-programs/

Walden, G., \& Trotsch, K. (2011). Apprenticeship training in Germany-still a future-oriented model for recruiting skilled workers? https://doi.org/10.1080/13636820.2011.570454

WEF. (2015). Is Europe outperforming the U.S.? Retrieved from https://www.weforum.org/agenda/2015/10/is-europe-outperforming-the-us/ 


\section{Macrothink}

International Journal of Global Sustainability

ISSN 1937-7924 2019, Vol. 3, No. 1

Werner, J. (2018). Retrieved from https://foreignpolicy.com/2018/08/08/china-is-cheatingat-a-rigged-game/

West, D. (2018). Will Robots and Automation take your job? Retrieved from https://www.brookings.edu/blog/techtank/2018/04/18/will-robots-and-ai-take-your-job-the-ec onomic-and-political-consequences-of-automation/

White, R. (2011). Railroaded: The Transcontinental and the Making of Modern America. New York: Norton

Williams, O. (2014). Corporate Social Responsibility: The role of business in sustainable development. New York: Routledge. https://doi.org/10.4324/9780203746752

Wired. (2018). Retrieved from https://www.wired.com/story/tech-companies-try-toretrain-the-workers-theyre-displacing/?verso=true

Wisman, J. (2013). Wage stagnation, rising inequality, and the financial crisis of 2008 . https://doi.org/10.1093/cje/bes085

World Bank. (2016). Retrieved from https://data.worldbank.org/indicator/GB.XPD. RSDV.GD.ZS

WTO. (2019). Global Trade Growth Loses Momentum as Trade Tensions persist. Retrieved from https://www.wto.org/english/news_e/pres19_e/pr837_e.htm

Zaffos, J. (2016). Retrieved from https://truthout.org/articles/can-we-learnfrom-europe-s-approach-to-laid-off-coal-miners/

Zhouying, J. (2004). Technological Progress in History: A survey of evolution and shift of research emphasis from hard-tech to soft tech development. International Journal of Technology Management and Sustainable Development, 3(2). https://doi.org/10.1386/ ijtm.3.2.133/0

Zuboff, S. (2019). The Age of Surveillance Capitalism. New York: Hachette.

\section{Copyright Disclaimer}

Copyright for this article is retained by the author(s), with first publication rights granted to the journal.

This is an open-access article distributed under the terms and conditions of the Creative Commons Attribution license (http://creativecommons.org/licenses/by/3.0/). 